\title{
Defining Risk Assessment Severity Level of Geographical Indication Product Salak Pondoh (Sallaca edulis cv Reinw) Sleman
}

\author{
Muhammad Prasetya Kurniawan, Wahyu Supartono, Anggoro Cahyo Sukartiko, \\ Rizky Brisha Nuary, Pipit Dwi Puspitasari, Hildha Nurmalasari Dewi, Rudi \\ Setyawan \\ Department of Agro-industrial Technology, Faculty of Agricultural Technology, \\ Universitas Gadjah Mada \\ Email: mpkurniawan@gmail.com, Telepon/ Fax: 0274-551219
}

\begin{abstract}
Assessing severity level of agricultural products, including those with geographical indication (GI), is important to properly maintain their quality level. This study aimed to identify risk types of GI products and define their severity levels. The identification of risk types and definition of severity levels of GI products had been done on Salak Pondoh Sleman, which has been certified since 2014. These two objectives had been achieved through two approaches: (1) the use of international/ national quality standards of horticultural products; and (2) in-depth interview with each business actor at all tier of the product's supply chain. The results are discussed in the paper.
\end{abstract}

Keywords: geographical indication, risk assessment, Salak Pondoh Sleman, severity level

\section{INTRODUCTION}

Geographical Indications certification for salak pondoh Sleman is a form of legal protection for excellent commodity that unauthorized parties are not allowed to use geographical indications if such use is likely to deceive the consumer society of the region of origin of the product. Geographical indications can be used to give added value in the commercialization of products and for social purposes (Conneely and Mahon, 2015). Salak Pondoh Sleman certified as a geographical indication products since 2014, with a specificity that is reflected from the sweetness of the fruit is still unripe and crunchy texture (HAKI and RGI Book, 2015).

In line with Teuber (2011), the growing consumer interest in product attributes such as origin, sustainability, traceability and authenticity has fuelled the demand for regional foods, regional specialties, regional differences in climate, varieties, and local production techniques. According to Conneely and Mahon (2015), protected geographical indication scheme's is essential to promote opportunities that link specific localities and regions to high quality food and food production, and through this to enable those places to create and retain value-added from that product or process.

Sleman district is the largest production region for salak pondoh in Indonesia with production dominated by reaching 662321 quintals, up about 34.13 percent over the previous year as many as 493764 quintals in 2013. The district Most of fruits are cultivated in Turi, Pakem and Cangkringan produced 97, 23 percent of the total production of Sleman (BPS Sleman, 2014). There are another areas of salak cultivation in Indonesia, such as Banjarnegara and Magelang, Central Java. Salak pondoh can be planted and harvested throughout the year (RGI Book, 2015). Unstandardized postharvest handling and poor distribution caused damage and also inauthentic cases which occur due to low performance good agricultural practices, good handling practices, and good manufacturing practices.

Defining the risk assessment of salak pondoh, as a geographical indication products, required precise quality control and standardization for compliance with the rules and peculiarities. Measuring their risk for damage plays important role to identify the supply chain disruptions caused by the activities of distribution and handling due to low facilities 
and infrastructure level. Defining risk measurement salak pondoh focused on reducing the potential for losses and damage. Risk analysis was conducted by using the information available from the agricultural harvest bark and distributor and systematically to determine the interaction between the salak and the environmental impact of postharvest. Quality standard for salak pondoh in Indonesia refers to the SNI No.01-3167-1992, while the quality standards at the ASEAN level serves to provide special provisions for each class and the tolerances allowed, fruits must be:

- Whole, undamaged

- Shows the varietal characteristics company

- Free from rot or damage that may make it unfit for human consumption

- Clean

- Practically free from visible foreign matter;

- Practically free of mechanical damage and / or physiological;

- Practically free of pests and damage caused by them affecting the general appearance of the produce

- Free of abnormal external moisture, excluding condensation followin g removal from cold storage; and

- Free from foreign smell and / or taste. (ASEAN Stan 19: 2010).

After harvesting, most of the
damage to the
distribution inappropriate packaging, can be
reduced by using cushions to give more
protection for fruits. Bamboo basket with a
capacity of $25-40 \mathrm{~kg}$ is the most common bulk
packaging to transport the fruits of the
harvest to exporters or processing
units. Regulatory structures are easily
deformed due to inappropriate facilities and
infrastructures. A lot of bruised fruit in the lives
of fellow fruit collisions and excessive charges.
Quality standards including packaging is still
intact in bunches placed in the center and
surroundings are placed grain leather that has
been separated from the bunch.

\section{METHODOLOGY}

Discussion and depth interview were conducted with the Association of Salak Pondoh Sleman well as the management of the
Community Protection of Geographical Indications Salak Pondoh Sleman (KPIG SPS), chairman of group of Farmers, individual farmer, collectors, traders, suppliers, retailers, and in supermarket level. Identification of the types of risks and defining the severity implemented using two approaches, namely (1) the quality standards of horticultural products internationally or nationally, and (2) in-depth interviews (in-depth interviews) on every business in every tier entire supply chain. The steps for this study were conducted by

- interviewing all the potential causes and the extent of damage and the risk

- determining inauthenticity that may arise at each stage and possible causes.

- determining the categories of damage and inauthenticity.

- analyzing the relationship between damage and inauthentic and causes (based on the GAP, SOP and GMP during processes).

- analyzing the possibility of damage and inauthentic as well as the severity of the condition that occurred

- identifying whether a potential significant damage and inauthentic or not.

Stakeholders should be understand in supply chain interdependencies, identifying potential risk factors, their likelihood, consequences and severities. Defining risk assessment is essential to preferably avoid the identified risks, or if not possible, at least mitigate, contain and control the product (Tummala and Schoenherr, 2011). In order to determine the extent of mechanical damage on salak fruits, three main operations were considered, namely, a) picking, b) packing and, c) delivery to the market. Samples of fruits were collected after completion of each operation and delivered to a laboratory with care to prevent fruits from further damage.

\section{RESULTS AND DISCUSSION}

\subsection{Determining grading system for severity}

Tracing and tracking salak pondoh as a geographical indication products became the main activity in defining the severity level and inauthenticity. Several factors that are inappropriate carried out based on the findings for distribution and verified by experts at all levels (Table 1). Qualitative measurements carried out by observing and measuring damage to the area and also the mechanical properties of fruits. The mechanical properties of fruit showed that their ability to withstand without 
damage and deterioration. Evaluation of the recommended handling practices to reduce the adverse effects of shock and vibration as the interaction mode of transport conditions, packaging, and roads as well as the settings in the package.

Table 1 . Grading system with considered value for severity.

\begin{tabular}{|c|c|l|}
\hline Grade & Value & \multicolumn{1}{|c|}{ Description } \\
\hline Very low & 1 & $\begin{array}{l}\text { Diameter or length of physical and } \\
\text { mechanical damage 0-10 mm, } \\
\text { inauthentic percentage 0-1\% }\end{array}$ \\
\hline Low & 2 & $\begin{array}{l}\text { Diameter or length of physical and } \\
\text { mechanical damage 10.1-15 mm, } \\
\text { inauthentic percentage 1-5\% }\end{array}$ \\
\hline Medium & 3 & $\begin{array}{l}\text { Diameter or length of physical and } \\
\text { mechanical damage 15.1-20 mm, } \\
\text { inauthentic percentage 5-10\% }\end{array}$ \\
\hline High & 4 & $\begin{array}{l}\text { Diameter or length of physical and } \\
\text { mechanical damage 20.1-25 mm, } \\
\text { inauthentic percentage 10-15\% }\end{array}$ \\
\hline Very high & 5 & $\begin{array}{l}\text { Diameter or length of physical and } \\
\text { mechanical damage } \geq 25 \mathrm{~mm}, \\
\text { inauthentic percentage }>15 \%\end{array}$ \\
\hline
\end{tabular}

Condition and types of damage were found during the distribution chain and the handling of potentially cause bruising, hardness and darken color of the fruit after peeling was measured and discussed for subsequent use as a basic for determining the severity. Most of them occur due to inappropriate arrangements or patterns of fruit in the package, the absence of protective material (cushion), and the impact between the fruit and packaging.

\subsection{Determining grading system for inauthenticity}

Inauthentic assessments were conducted by experts in each tire of the chain through discussion and depth interview with the stakeholder of each tier salak pondoh supply chain. Inauthentic was determined by identifying inauthenticity or non IG fruit but stated as salak pondoh Sleman which sell in each tier and market/retailer. Observation was conducted to track and trace them from IG farmer or group of IG Farmers with likelihood views of frequencies actions. Determ ining the level of authenticity 1 until 5 was a bit of a 'subjective' based on assessment to respondents (Table 2).
Table 2. Grading system with considered value for authenticity

\begin{tabular}{|c|c|l|}
\hline Grade & Value & Description \\
\hline Very rarely & 1 & $\begin{array}{l}\text { never happened in a span }>1 \\
\text { year }\end{array}$ \\
\hline Rarely & 2 & $\begin{array}{l}\text { never happened in a span }>6 \\
\text { months }\end{array}$ \\
\hline Medium & 3 & $\begin{array}{l}\text { never happened in a span } 3 \\
\text { months }\end{array}$ \\
\hline High & 4 & $\begin{array}{l}\text { never happened in a span } 1 \\
\text { month }\end{array}$ \\
\hline Very high & 5 & occurs at least once in 1 week \\
\hline
\end{tabular}

Based on observation, inauthenticity identified through the use of experts credibility, comparing the attributes attached to products that are authenticated with a standard product, the use of documents issued by the competent authority.

\subsection{Determining damage during distribution}

Table 3. Types of damage and its percentage during distribution

\begin{tabular}{|l|l|l|}
\hline $\begin{array}{l}\text { Stake } \\
\text { holder }\end{array}$ & $\begin{array}{l}\text { Number of } \\
\text { damage per } \\
\text { package }\end{array}$ & $\begin{array}{l}\text { Type of damage } \\
\text { and non } \\
\text { conformity }\end{array}$ \\
\hline Farmer & $3-4.5 \%$ & $\begin{array}{l}\text { Size and shape are } \\
\text { not uniform, } \\
\text { rupture, cut, } \\
\text { broken rind, } \\
\text { overripe }\end{array}$ \\
\hline $\begin{array}{l}\text { Group } \\
\text { of farmers }\end{array}$ & $5-6 \%$ & $\begin{array}{l}\text { cut, rupture, } \\
\text { broken rind, bruise, } \\
\text { rotten }\end{array}$ \\
\hline $\begin{array}{l}\text { Small } \\
\text { collector / } \\
\text { association }\end{array}$ & $3-4 \%$ & $\begin{array}{l}\text { Rupture, broken } \\
\text { rinds, bruise, rotten }\end{array}$ \\
\hline $\begin{array}{l}\text { Big } \\
\text { collector/as } \\
\text { sociation }\end{array}$ & $3-5 \%$ & $\begin{array}{l}\text { rupture, broken } \\
\text { rind, bruise, rotten }\end{array}$ \\
\hline Exporters & $\pm 4 \%$ & $\begin{array}{l}\text { rupture, broken } \\
\text { rind, bruise, rotten }\end{array}$ \\
\hline $\begin{array}{l}\text { Big } \\
\text { suppliers }\end{array}$ & - & - \\
\hline Retailers & $8-10 \%$ & $\begin{array}{l}\text { rupture, broken } \\
\text { rind, bruise, rotten }\end{array}$ \\
\hline $\begin{array}{l}\text { Domestic } \\
\text { consumer }\end{array}$ & $5 \%$ & $\begin{array}{l}\text { rupture, broken } \\
\text { rind, bruise, rotten }\end{array}$ \\
\hline $\begin{array}{l}\text { Overseas } \\
\text { consumer }\end{array}$ & - & \begin{tabular}{l} 
- \\
\hline
\end{tabular} \\
\hline
\end{tabular}

Some suppliers mixed different maturity, 
dimension, and size in the same packaging which sometimes over capacity. Based on the table 3, losses of salak were caused due to high mechanical damage during harvest and fruit diseases before harvest. At the level of traders because sorting activity is done visually, so often mixed among pieces of good quality with low quality fruit, as well as packaging that exceeds the capacity.

Tabel 4. Risk mapping for severity level in distribution system of salak pondoh Sleman

\begin{tabular}{|c|c|c|c|c|c|}
\hline \multirow{2}{*}{$\begin{array}{c}\text { Severity } \\
\text { score }\end{array}$} & \multicolumn{5}{|c|}{ Likelihood } \\
\hline & 1 & 2 & 3 & 4 & 5 \\
\hline 5 & & & & & \\
\hline 4 & & RR 3 & & & RR 1 \\
\hline 3 & & & RR 17 & RR 4 & \\
\hline 2 & & $\begin{array}{l}\text { RR 7, } \\
\text { RR 9 }\end{array}$ & & $\begin{array}{l}\text { RR 2, } \\
\text { RR 6, } \\
\text { RR } 8\end{array}$ & \\
\hline 1 & $\begin{array}{l}\text { RR 5, } \\
\text { RR 10, } \\
\text { RR 12, } \\
\text { RR 13, } \\
\text { RR 14, } \\
\text { RR 15, } \\
\text { RR 16, } \\
\text { RR } 18\end{array}$ & & & & $\begin{array}{l}\text { RR } \\
\mathbf{1 1}\end{array}$ \\
\hline
\end{tabular}

RR 1 = Land clearing; RR 2 = Plant nursery; RR 3 = Plant maintenance; $R R 4$ = Salak Postharvesting; $R R 5$ = Sorting at the farmers level; RR 6 = Transporting to group of farmers; $R R 7$ = Sorting at the farmer groups level; RR 8 = Transporting to the processing unit; RR 9 = Material handling; RR 10 = Weighing; $R R 11=$ Cleaning; $R R 12$ = Sorting at the processing unit level; RR 13 = Weighing; RR 14 = Packing; RR 15 = Labelling; $R R 16$ = Packing; $R R 17$ = Transporting to retailer $; R R 18=$ Sorting at retailer level; $R R 19=$ Storing at the retailer level

Color area information:

\begin{tabular}{|l|l}
\hline & $\begin{array}{l}\text { Acceptable } \\
\text { Supplementary Issue }\end{array}$ \\
\cline { 1 - 2 } Issue \\
Unacceptable
\end{tabular}

Land clearing and cleaning processes caused more damage to the fruits then prone to decay.

Tabel 5. Risk mapping for inauthenticity level in distribution system of salak pondoh Sleman

\begin{tabular}{|c|c|c|c|c|c|}
\hline \multirow{2}{*}{$\begin{array}{c}\text { Inauthen } \\
\text {-tic score }\end{array}$} & \multicolumn{5}{|c|}{ Likelihood } \\
\cline { 2 - 6 } & 1 & 2 & 3 & 4 & 5 \\
\hline 5 & & & & & \\
\hline 4 & & & & & \\
\hline 3 & & & & RO 5 & \\
\hline
\end{tabular}

\begin{tabular}{|c|c|c|c|}
\hline 2 & & & RO 7 \\
\hline 1 & \begin{tabular}{|l} 
RO 1, \\
RO 2, \\
RO 3, \\
RO 4, \\
RO 6, \\
RO 9, \\
RO 10, \\
RO 11, \\
RO 12, \\
RO 13, \\
RO 14, \\
RO 15, \\
RO 16, \\
RO 17, \\
RO 18, \\
RO 19
\end{tabular} & RO 8 & \\
\hline
\end{tabular}

RO 1 = Land clearing; RO 2 = plant nursery; RO 3 = Plant maintenance; $R O 4$ = Salak Postharvesting; RO 5 = Sorting at the farmers level; $R O 6=$ Transporting to group of farmers; $R O 7$ = Sorting at the farmer groups level; RO 8 = Transporting to the processing unit; RO 9 = Material handling; $R O 10$ = Weighing; RO 11 = Cleaning; RO 12 = Sorting at the processing unit level; RO 13 = Weighing; RO 14 = Packing; RO 15 = Labelling; RO 16 = Packing; $R O 17$ = Transporting to retailer $; R O 18=$ Sorting at retailer level; $R O 19$ = Storing at the retailer level

Sorting at the farmers level was the highes for potential forgery and inauthenticity. The percentage of inauthenticity level is rarely find and tolerable for domestic market.

\section{CONCLUSSION}

To maintain Superior Quality possessed of the geographical indication products start by analyzing the activity on each tier in the supply chain of salak pondoh Sleman. The development in technology, including postharvest technology, have been able to maintain the quality of existing food products, so that managerial and system approach can optimize the maintenances of the quality of the product to the hands of consumers. Identify risk types of GI products by using international and national quality standards of horticultural products. Severity level of salak pondoh can be defined by the skin areas where damage were occurred. Inspection and evaluation of postharvest handling and increase the ability of farmers harvesting, sorting, and documentation

of geographical indications for products highly recommended for the improvement and evaluation.

\section{ACKNOWLEDGEMENT}

We would like to express our sincere gratitude to the writers team and farmer and 
their group who kindly provided information

for in collecting data in the field.

\section{REFERENCES}

Central Bureau of Statistics (BPS). 2014. Agricultural Statistics Indonesia: Sleman District, D.I.Yogyakarta.

Conneely R and Mahon M. 2015. Protected geographical indications: Institutional roles in food systems governance and rural development. Geoforum 60, page 14-21.

Dimyati A, Kuntarsih S, Iswari D, and Nurcahya YS. 2009. Meeting the Requirements of International Market for Salacca, Case Study: Export Challenge of Salacca "Pondoh" Variety to China. Directorate General of Horticulture Ministry of Agriculture of the Republic of Indonesia.

Directorate General of Intellectual Property of the Ministry of Justice and Human Rights RoI. Registered Geographical Indications (HAKI Book). 31 March 2015. [Online]. Available:http://www.dgip.go.id/images/adelc h-images/pdffiles/publikasi/publikasi_ig/ig_terdaftar_maret _2015.pdf. [Accessed 27 September 2015.

Lubka Tchankova. (2002). Risk identification-basic stage in risk management. Environmental Management and Health, Vol. 13 Iss 3 pp. 290 $-297$.

National

Standardization Agency. Standard quality of salak fruit SNI 013167-1992, Jakarta: National Standardization Agency, 1992.

Ramona Teuber, (2011). Consumers' and producers' expectations towards geographical indications. British Food Journal, Vol. 113 Iss 7 pp. 900 918.

Rao Tummala Tobias Schoenherr. (2011). Assessing and managing risks using the Supply Chain Risk Management Process (SCRMP). Supply Chain Management: An International Journal, Vol. 16 Iss 6 pp. $474-483$

Registered Geographical Indication (RGI). Required Book. Salak Pondoh. (http://119.252.174.21/indikasigeografis/?book=salak-pondoh-slemansertikat) accessed $1^{\text {st }}$ September 2015.

V.M. Rao Tummala Y.H. Leung. (1996).A risk management model to assess safety and reliability risks. International Journal of Quality \& Reliability Management, Vol. 13 Iss 8 pp. $53-62$ 